\title{
Deep-water Fisheries of the Northeast Atlantic: I. Description and Current Trends
}

\author{
J. D. M. Gordon \\ Scottish Association for Marine Science, Oban, PA37 1QA, UK \\ O. A. Bergstad \\ Institute of Marine Research, Flodevigen Marine Research Station \\ N-4817 His, Norway \\ I. Figueiredo \\ IPIMAR, Avenida de Brasilia, 1400 Lisbon, Portugal \\ and \\ G. Menezes \\ Dept. of Oceanography and Fisheries, University of the Azores \\ 9900 Horta, Azores, Portugal
}

\begin{abstract}
Deep-water fisheries in the Northeast Atlantic originated as artisanal fisheries, and primarily use fixed gear such as longlines. During the late-1960s and 1970s, exploitation of deep-water species expanded into oceanic areas as vessels explored new offshore grounds using highly mechanized longline and trawl gear. In this paper we review most of the deep-water fisheries conducted in the Northeast Atlantic in slope waters greater than $400 \mathrm{~m}$ by summarizing historical developments and describing current trends.
\end{abstract}

Keywords: Atlantic, by-catch, continental slope, deep-sea, fisheries, fishes, ICES, longline, trawl

\section{Introduction}

\section{Major historical patterns}

Most deep-sea fisheries in the Northeast Atlantic originated as artisanal fisheries, particularly in southern Europe where the continental shelf is narrow and deep water is close to land, (e.g. in the Azores, mainland Portugal and southern Spain). In these southern regions, deep-water fishes are still landed primarily by small vessels using traditional gear (handlines or longlines). However, most deep-water catches in the Northeast Atlantic today stem from highly mechanized longline and trawl fisheries. The major expansion and industrialisation of these fisheries started after World War II, and has subsequently been accompanied by a steady improvement in vessels and gear technology and by dedicated exploration of new fishing grounds (often subsidized by national governments).

Mechanized longline fisheries for deep-water fishes were first developed in Scandinavia (Bergstad and Hareide, 1996). Deep-water longlining for ling (Molva molva), tusk (Brosme brosme) and halibut
(Hippoglossus hippoglossus) began off the coast of Norway and in the Skagerrak, and during the 1860s Swedish fishermen transformed the method from a coastal to a high-seas activity. Norway started using bigger vessels and by about 1900 steam ships began exploring new grounds off Shetland and the Faroe Islands. After World War II, vessel size increased to 18-27 $\mathrm{m}$ (60-90 feet) and fishing expanded to the offshore banks and slopes west of the British Isles and around Rockall. From the 1960s onwards, substantial efforts were made to explore new grounds and enhance the efficiency of the operation and gear. Vessel size has since further increased, and today a modern longliner is essentially a factory ship of $30 \mathrm{~m}$ (100 feet) or more, equipped with automatic baiting systems (autoline) and storage facilities permitting trips of 6-8 weeks or more. Norway alone operates 50-60 such vessels, and the same technology has been adopted by many other nations, e.g. the Faroe Islands, Iceland, Russia, Spain, and Ireland. Autoline systems are also now available for small vessels. Longlining is currently conducted in all slope areas of the Northeast Atlantic area, as well as on the continental shelf. 
Northeast Atlantic trawl fisheries for deep-water fishes developed along the continental margins of the western Atlantic and the Reykjanes Ridge and subsequently the continental margins of Europe following major USSR exploratory efforts in the 1960s and 1970s (Pechenik and Troyanovsky, 1970; Troyanovsky and Lisovsky, 1995). During the late1970 s, the loss of fishing opportunities in traditional shelf areas prompted Western European fleets to move into deeper waters, where considerable exploratory deep-water trawling was conducted by Germany and the UK (Bridger, 1978; Ehrich, 1983; Rätz, 1984). However, it was French trawlers that initiated major commercial operations in the mid-1980s, probably because of easy access to markets that readily accepted new species. Germany mainly concentrated on redfish (Sebastes spp.), and the UK gradually developed a fishery for anglerfish (Lophius spp). Current deepwater trawl fisheries are prosecuted mainly by French, Spanish, Faroese, Irish and Scottish vessels. Russian and Polish vessels are also active, especially on the Mid-Atlantic Ridge, at Rockall, and on the Hatton Bank.

Few longliners and trawlers have true deep-sea species as year-round targets. In northern waters, cod (Gadus morhua), redfish, and Greenland halibut (Reinhardtius hippoglossoides) are the main target species. In southern waters, seasonal changes between target resources on the shelf and slope also occur. This paper is primarily concerned with the true deep-water species, as defined in the terms of reference of the ICES (International Council for the Exploration of the Sea) Working Group on the Biology and Assessment of Deep-Sea Fisheries Resources (WGDEEP and its predecessor Study Group, SGDEEP). These are fish that generally occupy depths greater than about $400 \mathrm{~m}$ and which are poorly documented in a widely dispersed literature. Descriptions of the fisheries and their current status for other species that occur in deep-water, such as redfish, Greenland halibut, anglerfish and blue whiting can be found in the annual reports of the ICES Advisory Committee for Fisheries Management.

\section{Results}

\section{Fisheries by ICES Sub-area and Division}

The following geographical account summarises Northeast Atlantic deep-water fisheries by ICES Subareas and Divisions (Fig. 1) and is mainly based on information in Hopper (1995), Gordon (2001a), and on national reports submitted to the ICES WGDEEP and SGDEEP, or to the European Commission Deep-Water Fisheries Project (Gordon, 1999a; Gordon, 2001b). Species-specific landings data, by Sub-area, are given in Table 1 (extracted from Anon., MS 2002).

\section{ICES Sub-areas I and II}

Sub-areas I and II comprise the slope waters of western and northern Norway and Svalbard, where directed longline fisheries exist for ling and tusk. The Norwegian fleet comprises about 60 vessels, which also fish in ICES Sub-areas V, VI, VII and XIV. The fleet also has other preferred target species, at some times of year, notably for northeast Atlantic cod. The same fleet may also temporarily target redfish and Greenland halibut. There are also trawl and gillnet fisheries for redfish and Greenland halibut. A directed bottom and pelagic trawl fishery for greater silver smelt (Argentina silus) takes place along the edge of the continental margin (Johannessen and Monstad, MS 2001), and in some fjords, there are minor trawl fisheries for roundnose grenadier (Coryphaenoides rupestris) (Gordon, 1999a). Roughhead grenadier (Macrourus berglax) were taken as by-catch in the fisheries for Greenland halibut, and a significant bycatch of ling and tusk occurs in various trawl and gillnet shelf fisheries. A gillnet fishery off mid-Norway targets ling and sometimes blue ling (Molva dypterygia), but yields have declined to very low levels compared to the early-1980s when the fishery developed.

\section{ICES Sub-area III}

In the Skagerrak (Division IIIa), targeted deepwater fisheries exist for roundnose grenadier and greater silver smelt. The Norwegian fishery for greater silver smelt is conducted by 1-3 trawlers and the landings were 1000 to 2000 tons per annum in the late-1980s and early-1990s. Since then the catches have declined. However there may be significant bycatches of greater silver smelt in the Norwegian trawl fisheries for Norway pout (Trisopterus esmarkii), blue whiting (Micromesistius poutassou) and deep-water shrimp (Pandalus borealis). During the last 10 years a small number of Danish vessels have targeted greater silver smelt and roundnose grenadier. Most of the landed roundnose grenadier was used for meal and oil but a significant component of the greater silver smelt landings are used for human consumption. Small quantities of blue ling, rabbit fish (Chimaera monstrosa) and lantern shark (Etmopterus spinax) are occasionally landed as by-catch. 


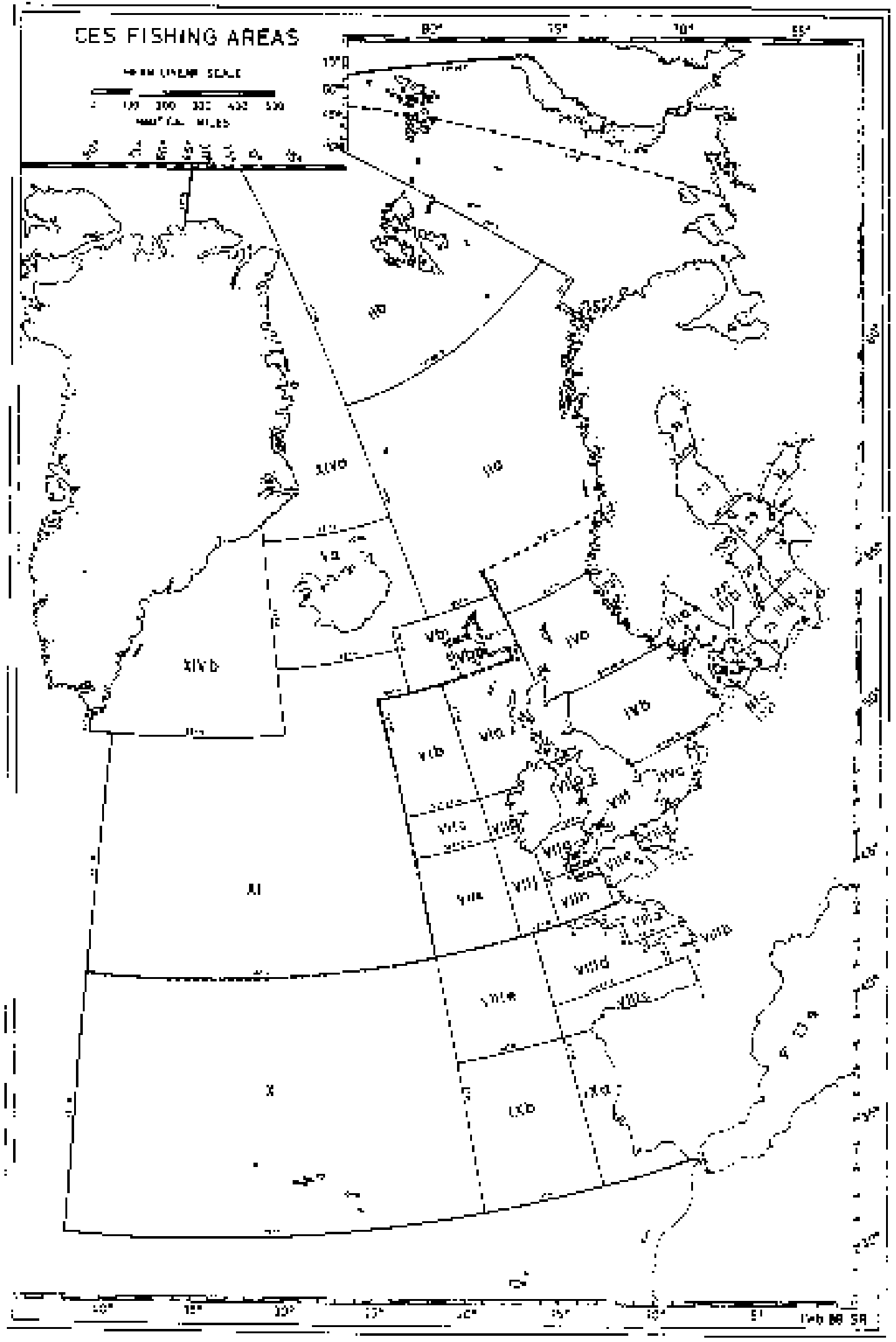

Fig. 1. ICES Sub-areas and Divisions in the North East Atlantic. 


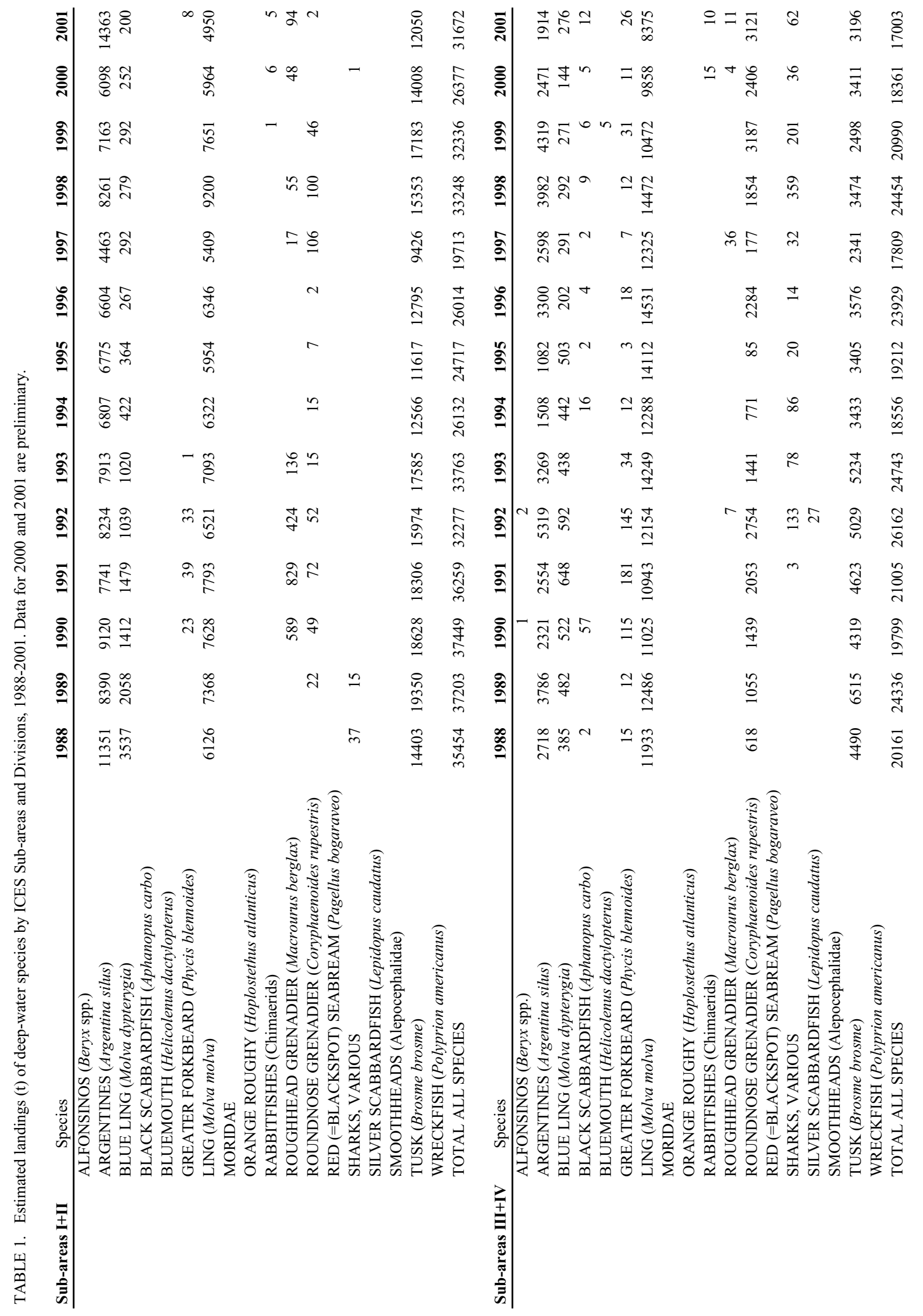


GORDON et al.: Deep-water Fisheries of the Northeast Atlantic: I.

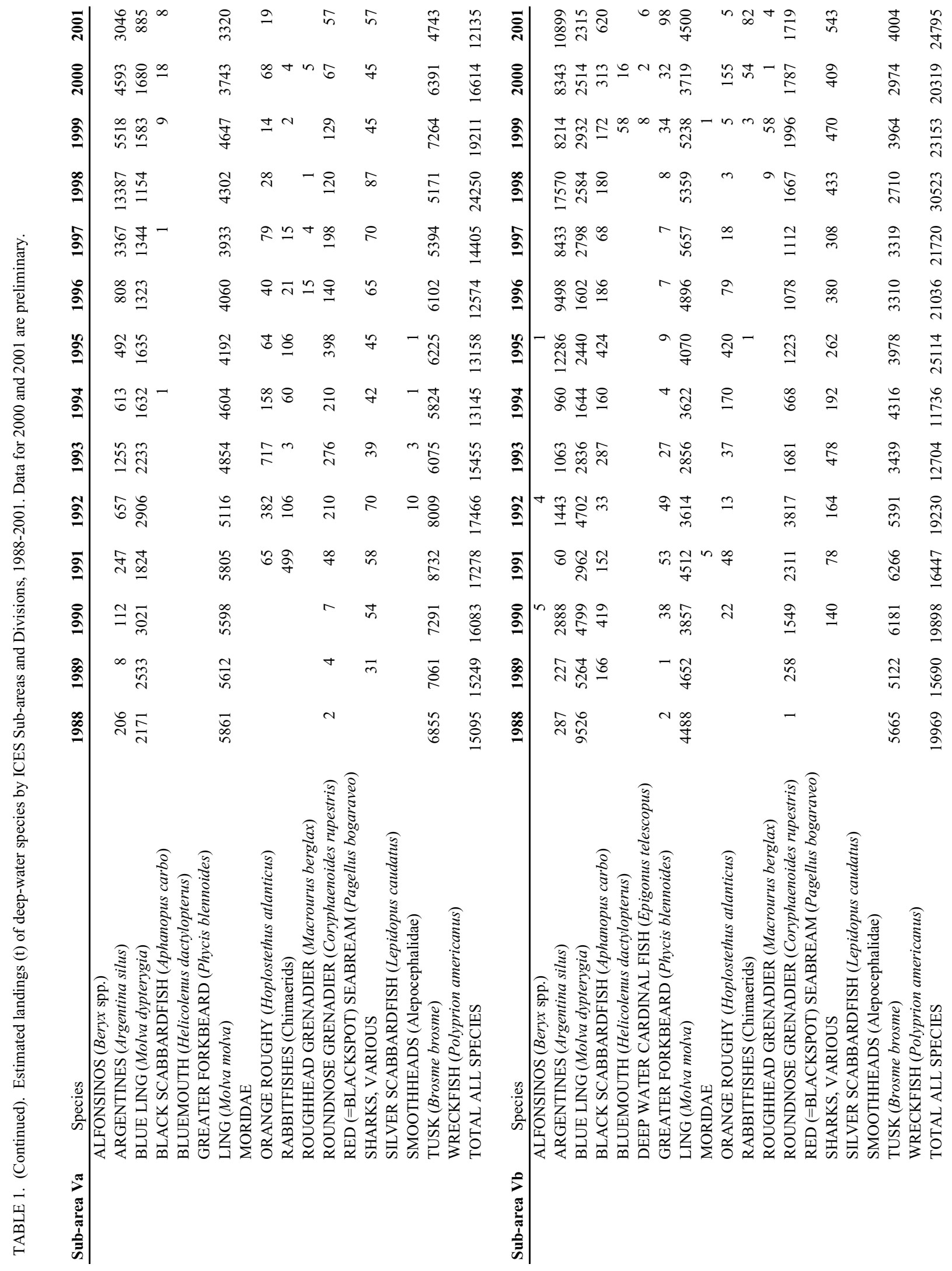




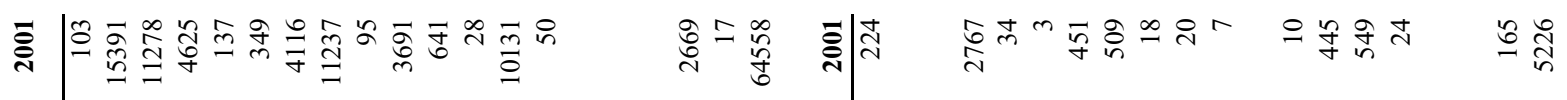

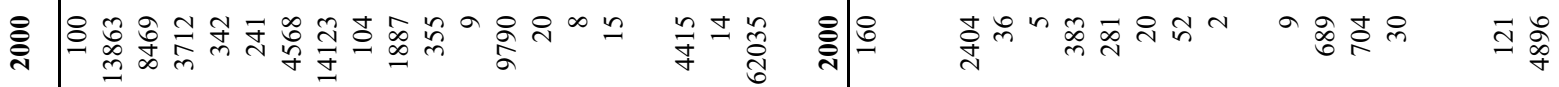

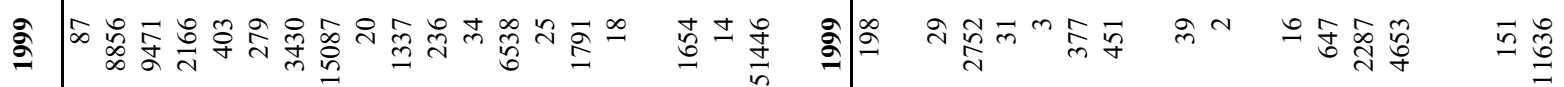

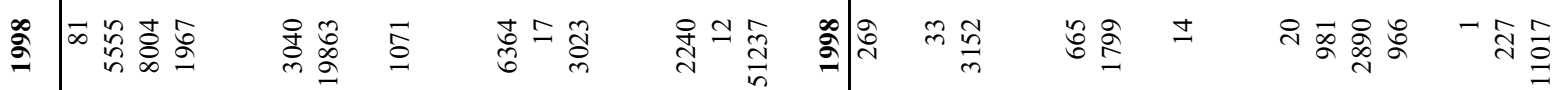

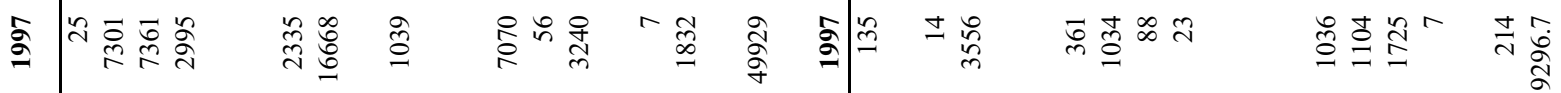

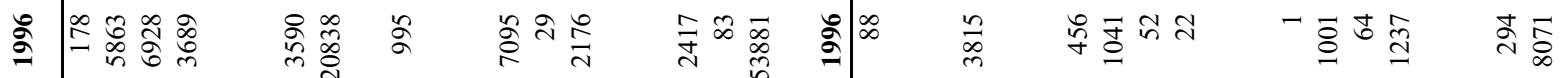

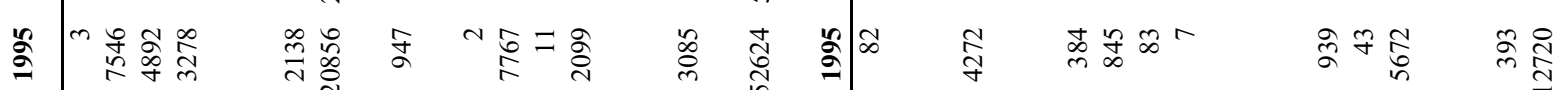

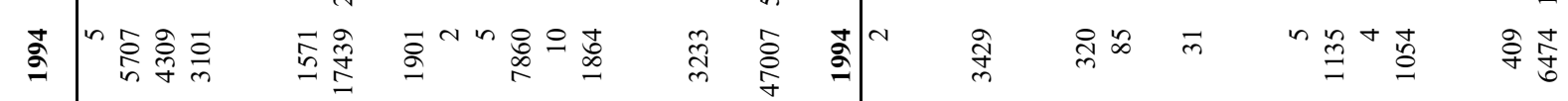

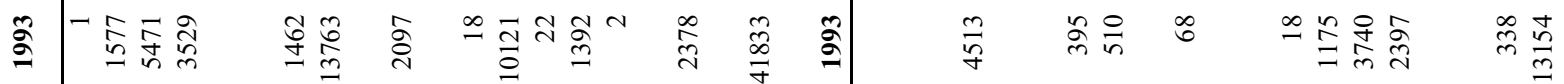

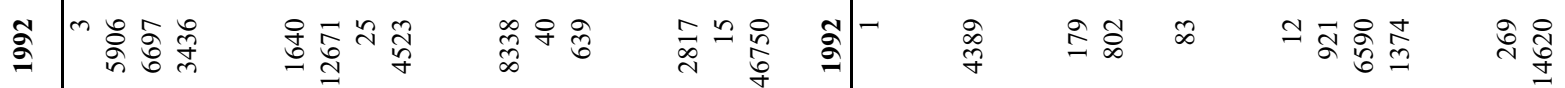

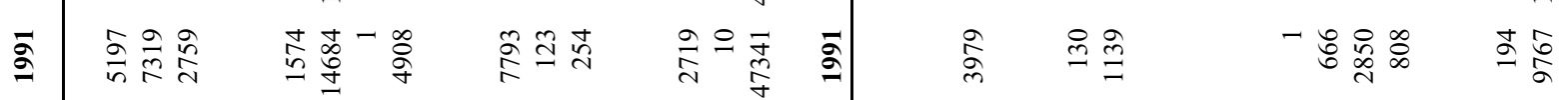

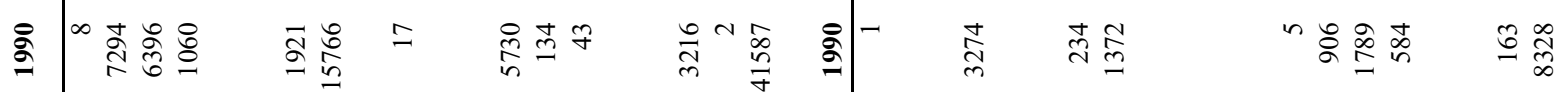

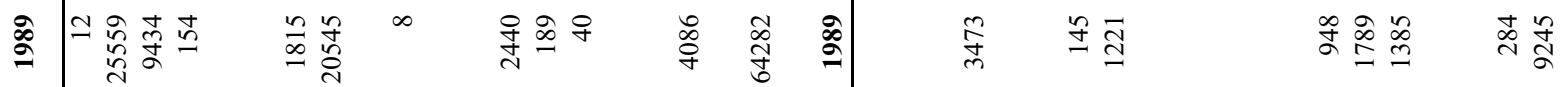

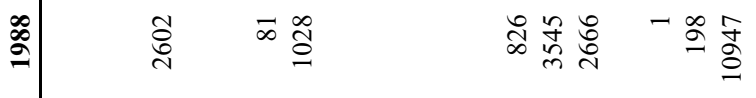
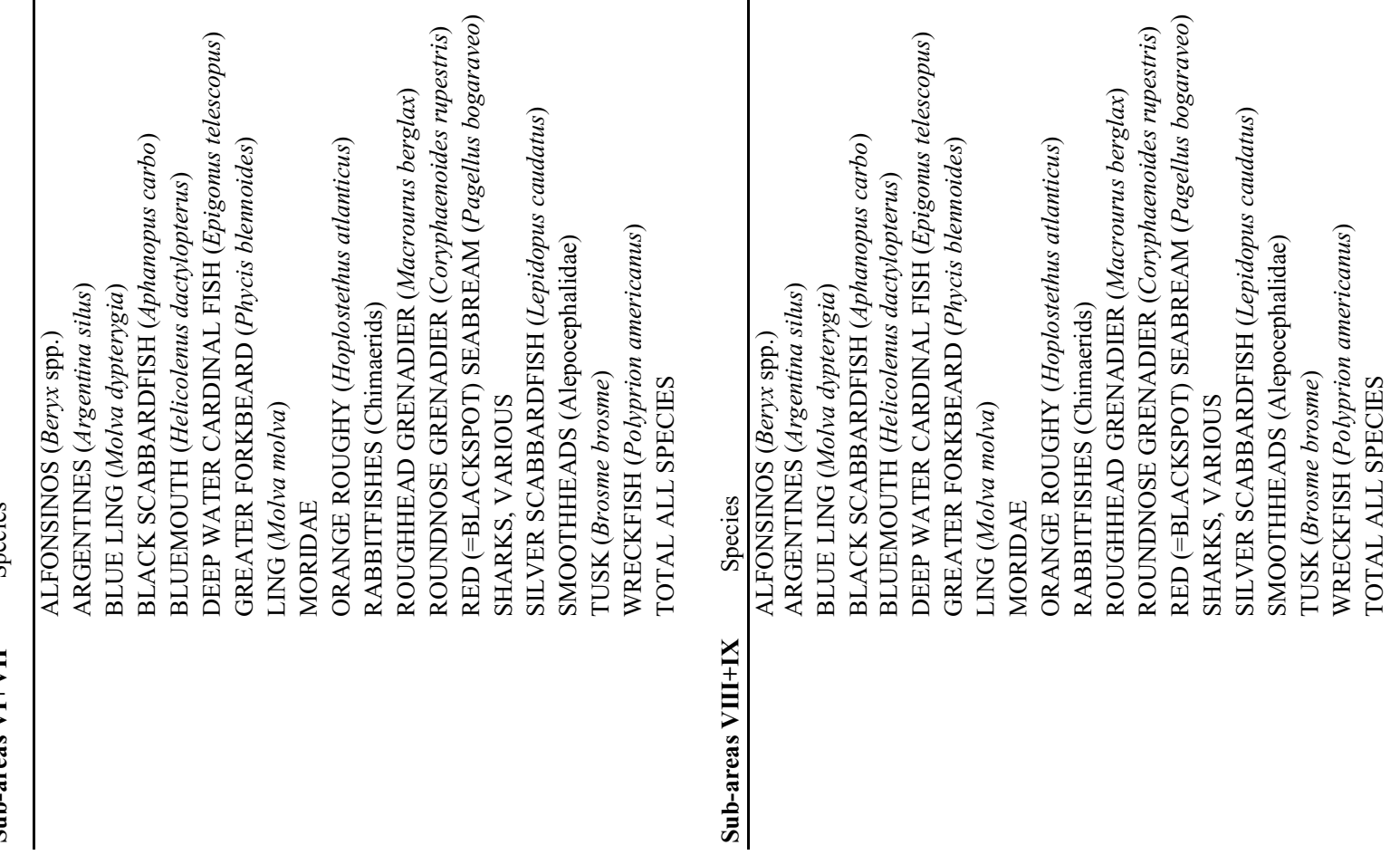
GORDON et al.: Deep-water Fisheries of the Northeast Atlantic: I.

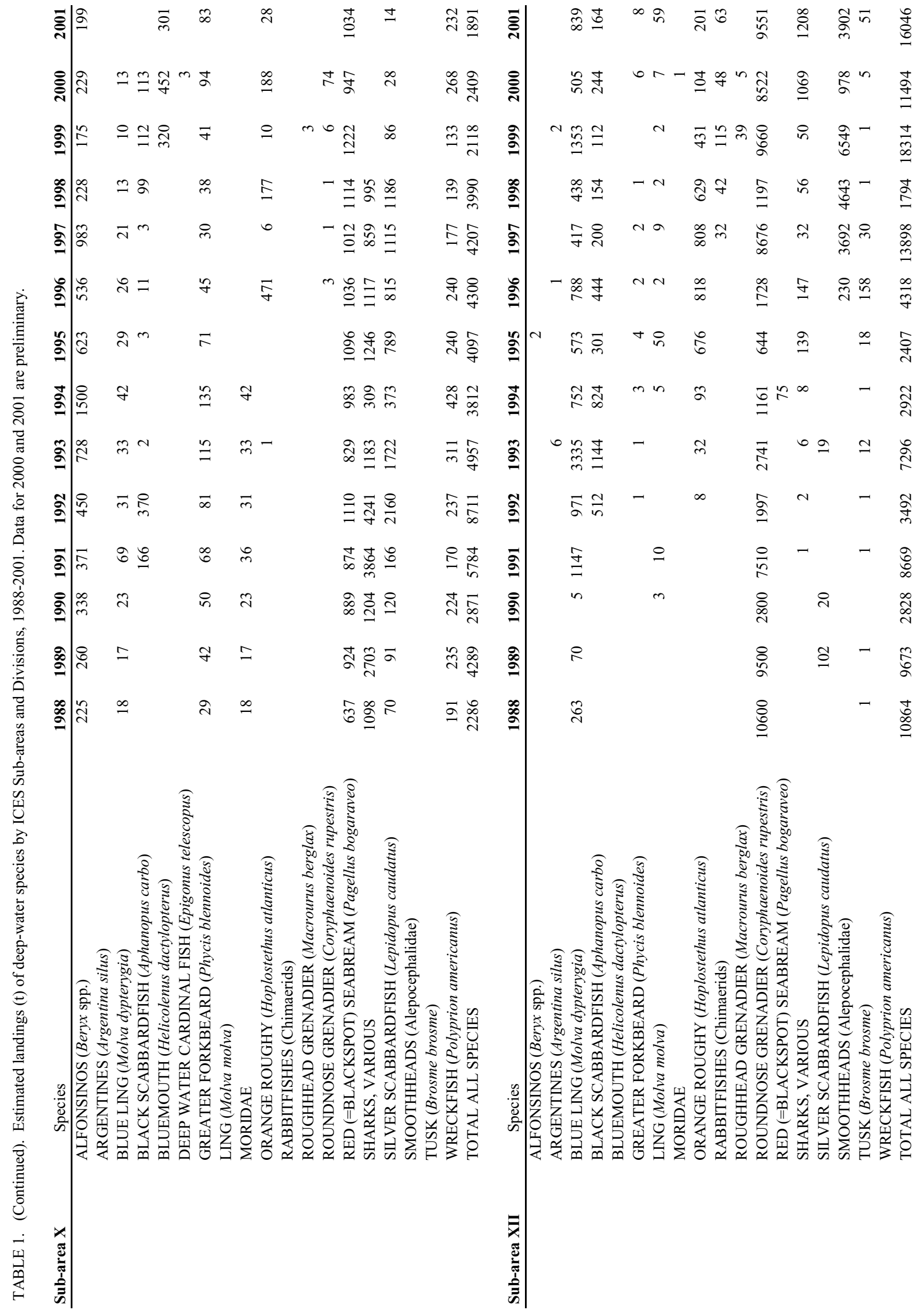




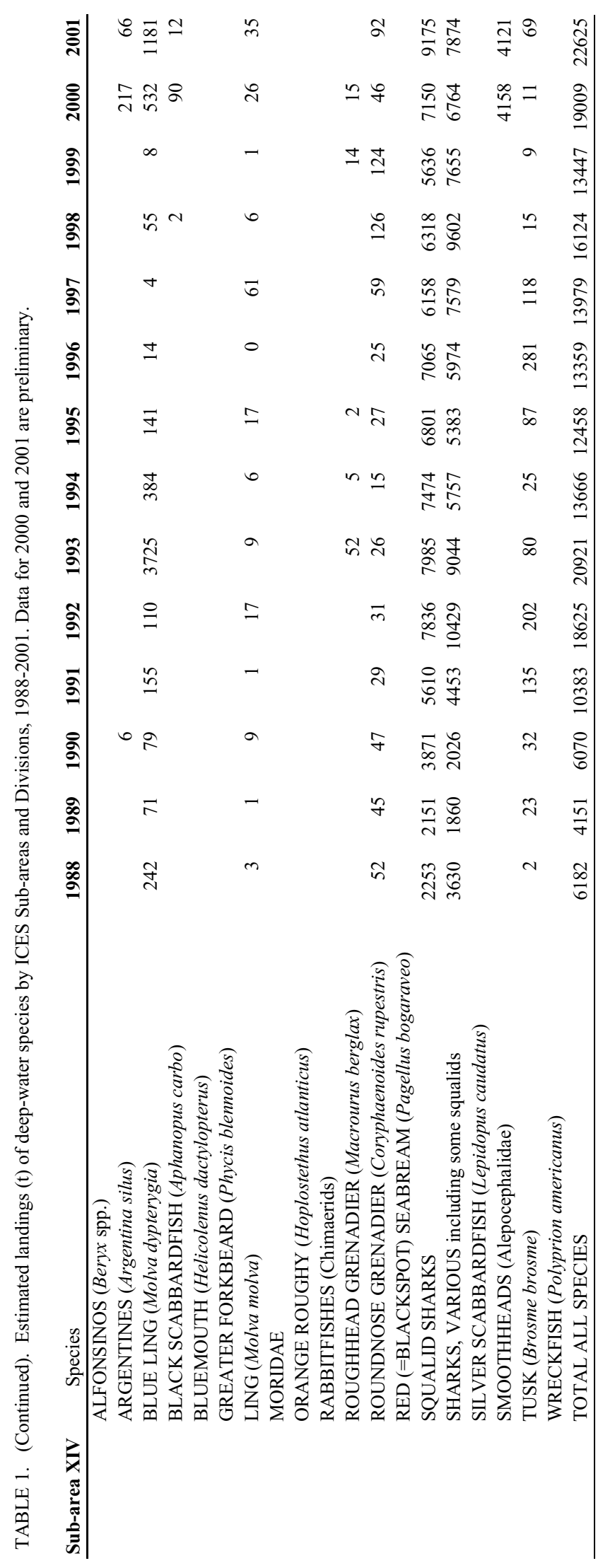




\section{ICES Sub-area IV}

In this Sub-area, significant longline fisheries for tusk and ling exist in the Norwegian Deep and also around Shetland and the Orkney Islands, which take greater forkbeard (Phycis blennoides) as a major bycatch. Greater silver smelt are caught in the industrial trawl fishery along the slope of the Norwegian Deep. In trawl fisheries targeting anglerfish (Lophius piscatorius) and Greenland halibut on the slope north and west of Shetland, some deep-water species such as ling are taken as by-catch (Bullough et al., 1998; Gordon, 2001c). At the upper slope front between the deep, cold Norwegian Sea water and the overlying warmer Atlantic water, Greenland halibut and redfish are targeted, with fisheries for both species extending onto the Faroese slope (Division $\mathrm{Vb}$ ) and across to Iceland (Division Va).

\section{ICES Sub-area $V$}

ICES Sub-area V is divided into two Divisions: Division Va covers the waters around Iceland and the northern part of the Reykjanes Ridge, while Division $\mathrm{Vb}$ covers the waters around the Faroe Islands. The deep-water areas in both Divisions have different hydrographic regimes resulting from the separation by underwater ridges of warmer Atlantic waters from colder Norwegian Sea waters.

\section{ICES Division $\mathrm{Va}$}

Deep-water fishing was first documented around Iceland in the 1930s but it was not until the 1970s that the fisheries for deep-sea redfish (Sebastes mentella) and Greenland halibut became prominent (Magnússon, MS 1998; Magnússon et al., 2000). Other species targeted with varying intensity include blue ling, orange roughy (Hoplostethus atlanticus) and greater silver smelt. Deep-water species landed incidentally include roundnose grenadier, roughhead grenadier, deep-water chimaerids, and sharks.

Deep-sea redfish was not recognised as a distinct species from S. marinus until 1951. The two species are typically landed together, and only since 1978 have the proportions of the two species in the catches been estimated for scientific purposes. The bottom trawl fishery for deep-sea redfish occurs on the slope at depths of 500 to $700 \mathrm{~m}$ and is conducted primarily along the west, south and southeast coasts of Iceland. During autumn, both bottom and midwater trawls target spawning aggregations on the Reykjanes Ridge and off the south coast of Iceland.
The bottom trawl fishery for Greenland halibut that began in the 1960s concentrated along the western slopes, and was mainly prosecuted by non-Icelandic vessels. Iceland began a directed longline fishery off the north coast in 1969. The spring trawl fishery on aggregations to the west of Iceland continues, but there are also landings from other areas throughout the year.

Landings of blue ling are mainly a by-catch of the redfish fishery, although in some years directed fisheries have occurred on spawning aggregations. Landings of greater silver smelt are variable because of technical and marketing problems. Landings of orange roughy are spasmodic and depend on fishing local aggregations that are generally difficult to locate.

\section{ICES Division $\mathrm{Vb}$}

Ling and tusk fisheries in Division $\mathrm{Vb}$ are primarily conducted by Faroese and Norwegian longliners, especially in area Vb2 (Anon., MS 1998, MS 2000). The principal deep-water bottom trawl fisheries in Division $\mathrm{Vb}$ are associated with warm Atlantic waters and are closely linked with the deepwater fisheries in Sub-area VI (see below). The mixed bottom trawl fishery, mainly prosecuted by France and the Faroe Islands, lands species such as roundnose grenadier, black scabbardfish (Aphanopus carbo) and blue ling. Targeted trawl and gillnet fisheries also exist for Greenland halibut and anglerfish. The gillnet fishery also produces a by-catch of deep-sea red crab (Chaceon (formerly Geryon) affinis). Trap fisheries have also occurred for this crab species (Reinert, 1995). A Faroese targeted longline fishery on two species of deep-water sharks, Portuguese dogfish (Centroscymnus coelolepis) and leafscale gulper shark (Centrophorus squamosus), has recently been developed. Exploratory fishing for orange roughy has also been conducted in this Division (and over the wider ICES area) (Thomsen, MS 1998).

\section{ICES Sub-areas VI and VII}

The deep-water fisheries of Sub-areas VI and VII are customarily considered as a unit because a significant proportion of the landings in both Subareas are from the continental slope that extends from the north of Scotland to the northern Bay of Biscay. Sub-area VI also includes the slopes of the Rockall Bank, various banks forming the northern boundary of the Rockall Trough, and a portion of the Hatton Bank (Division VIb). A portion of the Hatton Bank also lies within Sub-area XII and this can cause reporting problems (see below). Prior to 1976 when 
the UK claimed a 200-mile fishery limit around Rockall, various deep-water trawl fisheries were conducted in international waters around the offshore banks, mostly by the USSR. After the UK relinquished its 200-mile claim in 1997, there has been an uncontrolled expansion of deep-water fisheries to the west of the Rockall Bank and at Hatton Bank.

The deep-water fisheries in Sub-areas VI and VII can be subdivided into bottom trawl, semi-pelagic, longline and gillnet fisheries and have recently been reviewed by (Gordon, 2001c). The bottom trawl fisheries are for mixed demersal species with blue ling and roundnose grenadier as the main target species, and black scabbardfish and deep-water sharks as the main by-catch. On the upper slopes, anglerfish is a target species, and in deeper waters, usually on steeper slopes, there is a directed fishery for orange roughy. France has dominated the bottom trawl fishery, but Ireland and the UK have recently increased their landings. Significant landings of orange roughy (2 367 t) were made by Ireland in Sub-area VII in 2001. The semi-pelagic fisheries are for blue whiting and greater silver smelt. There are two separate longline fisheries, one for hake and the other for ling and tusk. Gillnet fisheries for anglerfish are prosecuted in international waters with a by-catch of deep-sea red crab.

\section{ICES Sub-area VIII}

Both longline and trawl deep-water fisheries exist in Sub-area VIII (Piñeiro et al., 2001). Off the northern coast of Spain (Division VIIIc), Spanish longline fisheries generally target greater forkbeard, while the longline fleets in the northwestern ports of Spain target alfonsino (Beryx splendens), greater forkbeard and red (blackspot) seabream (Pagellus bogaraveo). These longline fisheries are seasonal, occurring in winter and spring. By-catch species are deep-sea cardinal fish (Epigonus telescopus) and black scabbardfish. Directed fisheries for deep-water sharks exist in Division VIIIa, b, c, d-and in Division IXa. These shark fisheries, some of which take place year round, occur at depths between 900 and $1300 \mathrm{~m}$ and are prosecuted by vessels that formerly fished for hake. An important factor in determining the viability of the shark fisheries is the value of shark livers. In the Bay of Biscay (Division VIII a, b and d), a deepwater longline fishery developed in 1996 that lands a variety of species. In Division VIIIc, a specialized gillnet ('rasco') fishery occurs for anglerfish.
Several trawl fisheries targeting hake, megrim (Lepidorhombus whiffiagonis), anglerfish and Norway lobster (Nephrops norvegicus) have by-catches of deep-water species. These by-catches include ling, forkbeard (Phycis phycis), greater forkbeard, red (blackspot) seabream, conger eel (Conger conger), bluemouth (Helicolenus dactylopterus), wreckfish (Polyprion americanus) and alfonsinos.

The Galician Bank that lies partly in Division VIIIc and partly in Division IXb supports a small, fishery for the deep-sea red crab.

\section{ICES Sub-area IX}

In Sub-area IX, a Portuguese longline fishery for black scabbardfish takes place at depths between 800 and $1200 \mathrm{~m}$ on hard bottoms along canyon slopes (Gordon, 1999a). In 2000, 15 vessels were engaged in this fishery, which has a by-catch of Portuguese dogfish (Centroscymnus coelolepis) (Figueiredo et al., MS 2001a).

Off the south and southwest coasts of Portugal, a deep-water bottom trawl fishery for rose shrimp (Parapenaeus longirostris) and Norway lobster is conducted at depths between 200 and $700 \mathrm{~m}$ (Gordon, 1999a). The deepest grounds (400 to $700 \mathrm{~m}$ ) are only fished when Norway lobster is the target species. Bycatch species from the deeper fishing grounds include blue and red shrimp (Aristeus antennatus), giant red shrimp (Aristeomorpha foliacea), conger eel, bluemouth, greater forkbeard and blackmouth catshark (Galeus melastomus). Some potential also exists in the trawl fisheries for exploiting deeper-living shrimps such as A. antennatus, A. foliacea and Aristaeopsis edwardsiana (Figueiredo et al., 2001b).

In northern Portugal, a directed longline fishery for deep-water sharks exists which targets gulper shark (Centrophorus granulosus), but that occasionally lands leafscale gulper shark (Centrophorus squamosus), Portuguese dogfish, blackspot seabream, greater forkbeard and conger eel (Gordon, 1999a). Three species of scorpaenid fishes (red scorpionfish (Scorpaena scrofa), bluemouth, and Kuhl's scorpion-fish (Pontinus kuhlii)) are also taken in deep-water longline fisheries, but these species are not always separated in the landings. Most of the bycatches of deep-water bluemouth occur in the longline fishery for conger eel. 
Hake are fished in deep water using trawls, gill nets, trammel nets and longlines. Off the southern coast of Portugal, a semi-pelagic ("pedra-bola") longline fishery for hake takes place on the continental slope at depths between 200 and $700 \mathrm{~m}$ (Erzini et al., 2001). Deep-water species taken as by-catch in this fishery include the larger blackmouth catsharks, Ray's bream (Brama brama), conger eel, bluemouth and red (blackspot) seabream.

In the Straits of Gibraltar, an artisanal hook and line fishery (known as 'voracera'), began in the early1980s and targets red (blackspot) seabream at depths between 400 and $800 \mathrm{~m}$. The number of vessels in the fishery, which are all small (6-9 $\mathrm{m}$ in length), totalled over one hundred in 1999 (Gil et al., MS 2000 cited in Anon., MS 2000).

An occasional bottom trawl fishery for deep-water species occurs on the Galician slope in Division IXa (Piñeiro et al., 2001).

\section{ICES Sub-area X}

The deep-water fisheries in this oceanic Sub-area are confined to the slopes and seamounts of the Azorean Archipelago and parts of the Mid-Atlantic Ridge. Within the Azorean EEZ, handline and longline fisheries catch red (blackspot) seabream, wreckfish, conger eel, bluemouth, Kuhl's scorpionfish, greater forkbeard, and alfonsinos (Beryx splendens and $B$. decadactylus). Other species like mora (Mora moro) are also taken. Before the 1980 s, the handline fishery predominated, but in the early-1980s larger vessels and longlining technology were introduced and have since accounted for the majority of the landings. The traditional deep-water stocks of the Azores are now considered to be intensively or fully exploited, and some local management actions have recently been implemented.

A deep-water gillnet fishery for kitefin shark (Dalatias licha) flourished from the late-1970s until the early-1990s, with landings approaching 1000 tons in some years (Silva, MS 1987; Gordon, 1999b). However, catches have since declined to incidental levels and attempts to restart a directed fishery have not been successful due to marketing problems (Anon., MS 2000).

Longliners from Madeira have fished for black scabbardfish in this Sub-area since 1998. Some commercial fishing experiments for deep-water crabs and shrimps, were also undertaken in 1998 and 1999
(Pinho et al., 2001). In 2001, a major expansion of the black scabbardfish fishery in the Azores was anticipated. Exploratory fishing for orange roughy has occurred as well.

Outside the Azorean EEZ, trawl fisheries have been conducted (primarily by USSR/Russia) for alfonsinos (Beryx spp.), orange roughy, cardinal fish, black scabbardfish and wreckfish (Troyanovsky and Lisovsky, 1995; Vinnichenko, MS 1998).

\section{ICES Sub-area XII}

This vast Sub-area extends from 48 to $62^{\circ} \mathrm{N}$ and the areas relevant to deep-water fishing are the MidAtlantic Ridge, the Reykjanes Ridge, and parts of the Hatton Bank. USSR trawl fishing on the Mid-Atlantic Ridge began in the 1970 s targeting roundnose grenadier and alfonsino (Vinnichenko, MS 1998; Vinnichenko and Khlivnoy, MS 2001 (cited in Anon., MS 2001). Russian and Icelandic vessels occasionally reported catches of orange roughy in this area, but a directed fishery for orange roughy (by the Faroe Islands) did not develop until the mid-1990s (Thomsen, MS 1998). Norwegian and Icelandic longliners began fishing in this Sub-area and Division XIVb for 'giant redfish' (Sebastes marinus) on the Reykjanes Ridge with tusk, and Greenland halibut as significant by-catch in 1996 (Hareide and Garnes, 2001). The number of vessels engaged in the fishery declined in subsequent years indicating that the fishery is no longer viable at the 1996 level.

Multispecies trawl and longline fisheries occur on Hatton Bank (part of which lies in this Sub-area and part in Sub-area VI). There is considerable exploratory fishing on the Bank, and effort seems to be increasing (see Anon., MS 2000, MS 2001). However, Hatton Bank landings are difficult to determine because under the current reporting system landings from the Bank cannot be separated from those from either the Mid-Atlantic Ridge or the Rockall Trough.

\section{ICES SUb-area XIV}

In Sub-area XIV, directed trawl and longline fisheries occur for Greenland halibut and redfish having by-catches of roundnose grenadier, roughhead grenadier and tusk. In the Norwegian longline fishery for Greenland halibut off southeastern Greenland at depths down to $1500 \mathrm{~m}$ about $30 \%$ of the by-catch can be roughhead grenadier. A similar problem exists (as on Hatton Bank in Sub-area XII) in separating 
landings from the western part of the Mid-Atlantic Ridge (Reykjanes Ridge) from those taken on the slope off East Greenland.

\section{The Canary and Madeira Island Groups}

Although these island groups lie beyond the southern limit of the ICES area, the fisheries here have affinities with the Azorean fisheries in Sub-area $X$. The deep-water fishery off Madeira primarily targets black scabbardfish, with Portuguese dogfish as an important by-catch (Merrett and Haedrich, 1997, Reis et. al., MS 2002).

In the Canary Islands, small boat handline and longline fisheries occur year-round, targeting a wide variety of deep-water species including alfonsinos, wreckfish, forkbeards and mora (Rico et al., 1999). A seasonal fishery for hake occurs in deep water off Gran Canaria, and a small trap fishery exists for the deepwater shrimp (Plesionika edwardsi) at depths between 150 and $300 \mathrm{~m}$ (Gonzalez et al., 1997).

\section{Discussion}

\section{Exploratory fishing}

Exploratory fishing continues today in slope waters and on oceanic seamounts, either as relatively minor private enterprises or as partly governmentfunded programmes. Spain is conducting experimental fishing using various gear types on the Mid-Atlantic Ridge and on the Hatton Bank (Duran Muñoz and Román, MS 2000; Duran Muñoz et al., MS 2000), and Norway is exploring the Hatton Bank, primarily with longlines (Langedal and Hareide, MS 2000). Fishing effort has significantly increased on the Hatton Bank, but has recently declined on the MidAtlantic Ridge due to marked reductions in yields, particularly of redfish, tusk and halibut. There is currently a growing interest in fishing greater silver smelt at Iceland and black scabbardfish in the Azores. Ireland has carried out extensive deep-water fishing trials in 2001 in ICES Sub-areas VI and VII, but also with some surveys on the Mid-Atlantic Ridge.

\section{The Need for Regulation Due to Stock Depletion}

Many of the deep-water stocks in the Northeast Atlantic are heavily exploited and some are severely depleted (Anon., 2001). In 2000, this led ICES to conclude "most exploited deep-water species (in the Northeast Atlantic) are, at present, considered to be harvested outside safe biological limits" and to provide management advice recommending "immediate reductions in these fisheries unless they can be shown to be sustainable. New fisheries should be permitted only when they expand very slowly, and are accompanied by programs to collect data which allow evaluation of stock status." (Anon., 2001). The high vulnerability of deep-sea fish stocks to exploitation raises the question as to the extent to which yields from these resources are sustainable. A growing debate has ensued, especially with regard to the most vulnerable species such as orange roughy, roundnose grenadier, etc. A full account of this matter is beyond the scope of this paper, but more information on this issue can be found in Anon. (2001) and in the accompanying paper by Large et al. (2002).

\section{Acknowledgements}

We thank all the members/participants of the ICES Study/Working Groups on the Biology and Assessment of Deep-Sea Fisheries Resources for their contributions in providing data and analyses used in this manuscript. We also thank the anonymous referees for useful comments and advice.

\section{References}

ANON. MS 1998. Report of the Study Group on the Biology and Assessment of Deep-Sea Fisheries Resources for 1998. ICES C.M. Doc., ACFM:12, 172 p.

ANON. MS 2000. Report of the Study Group on the Biology and Assessment of Deep-Sea Fisheries Resources. ICES C.M. Doc., ACFM:8, 205 p.

ANON. MS 2001. Report of the Working Group on the Biology and Assessment of Deep-sea Fisheries Resources. ICES C.M. Doc., ACFM:23, 38 p.

ANON. 2001. Report of the ICES Advisory Committee on Fisheries Management, 2000. ICES Coop. Res. Rep., No. 242, $911 \mathrm{p}$.

ANON. MS 2002. Report of the Working Group on the Biology and Assessment of Deep-Sea Fisheries Resources. ICES C.M. Doc., ACFM:16.

BERGSTAD, O. A., and N.-R. HAREIDE. 1996. Ling, blue ling and tusk of the north-east Atlantic. Fisken og Havet, $15,126 \mathrm{p}$.

BRIDGER, J. P. 1978. New deep-water trawling grounds to the west of Britain. Ministry of Agriculture, Fisheries and Food, Directorate of Fisheries Research, Fisheries Laboratory, Lowestoft, UK, Laboratory Leaflet No. 41, $40 \mathrm{p}$.

BULlOUGH, L. W. , W. R. TURRELL, P. BUCHAN, and I. G. PRIEDE. 1998. Commercial deep water trawling at sub-zero temperatures - observations from the Faroe-Shetland Channel. Fish. Res., 39: 33-41.

DURAN MUÑOZ, P., and E. ROMÁN. MS 2000. Spanish experimental fishings: a cooperative research initiative between scientists and the local fishing industry. ICES C.M. Doc., W:03, 18 p. 
DURAN MUÑOZ, P., E. ROMÁN, and F. GONZÁLEZ. MS 2000. Results of a deep-water experimental fishing in the North Atlantic: An example of a cooperative research initiative with the fishing industry. ICES C.M. Doc., W: 04, 15 p.

EHRICH, S. 1983. On the occurrence of some fish species at the slopes of the Rockall Trough. Arch. Fischereiwiss., 33: $105-150$

ERZINI, K., J. M. S. GONÇALVES, L. BENTES, P. G. LINO, and J. RIBEIRO. 2001. The hake deepwater semi-pelagic ("pedra-bola") longline fishery in the Algarve (southern Portugal). Fish. Res., 51: 327-336.

FIGUEIREDO, I, P. D. MACHADO, and O. MOURA. MS 2001a. Portugal mainland contribution to the 2001 Report of the ICES Study Group on the Biology and Assessment of Deep-sea Fisheries Resources. Working Document, ICES Study Group on the Biology and Assessment of Deep-Sea Fisheries Resources, 8 p.

FIGUEIREDO, M. J., I. FIGUEIREDO, and P. B. MACHADO. 2001b. Deep-water penaeid shrimps (Crustacea: Decapoda) from off the Portuguese continental slope: an alternative future resource? Fish. Res., 51: 321-326.

GIL, J., I. SOBRINO, and M. P. JIMENEZ. MS 2000. A brief description of the Strait of Gibraltar red seabream (Pagellus bogaraveo) fishery. Report of the ICES Study Group on the Biology and Assessment of Deep-sea Fisheries Resources. Working Document, ICES Study Group on the Biology and Assessment of Deep-Sea Fisheries Resources, $6 \mathrm{p}$.

GONZÁLEZ, J. A., V. M. TUSET, I. J. LOZANO, and J. I. SANTANA, 1997. Biology of Plesionika narval (Crustacea, Decapoda, Pandalidae) around the Canary Islands (Eastern Central Atlantic). Estuar. Coast. Shelf Sci., 44: 339-350.

GORDON, J. D. M. (ed.). 1999a. Final Consolidated Report of European Commission FAIR Contract 95- 0655 Developing deep-water fisheries: data for the assessment of their interaction with and impact on a fragile environment, 1090 p. (also available as pdf file on www.sams.ac.uk)

GORDON, J. D. M. 1999b. Management considerations of deep-water shark fisheries. In: Case studies of the management of elasmobranch fisheries. R. Shotton (ed.). FAO Fish. Tech. Pap., No. 378: 774-818.

GORDON, J. D. M. (ed.). 2001a. Deep-Water Fish and Fisheries. A selection of papers presented at the ICES Annual Science Conference in Lisbon, Portugal 16-18 September 1998. Fish. Res. (Special Issue), 51: 105-418.

GORDON, J. D. M. 2001b. Deep-water fish and fisheries: introduction. Fish. Res., 51: 105-111.

GORDON, J. D. M. 2001c. Deep-water fisheries at the Atlantic Frontier. Cont. Shelf Res., 21: 987-1003.

HAREIDE, N.-R., and G. GARNES. 2001. The distribution and catch rates of deep water fish along the Mid-Atlantic Ridge from 43 to $61^{\circ}$ N. Fish. Res., 51: 297-310.

HOPPER, A. G. (ed.) 1995. Deep-water fisheries of the NorthAtlantic Oceanic Slope. Kluwer Academic Publishers, The Netherlands, $420 \mathrm{p}$.

JOHANNESSEN, A., and T. MONSTAD. MS 2001.
Distribution, growth and exploitation of greater silver smelt (Argentina silus) (Ascanius) in Norwegian waters 1980-1983. NAFO SCR Doc., No. 110, Serial No. N4498, $17 \mathrm{p}$.

LANGEDAL, G., and N.-R. HAREIDE. MS 2000. Rapport fra forsoksfiske med line paa Hatton Bank, M/S Loran, 2000. Report, The Norwegian Directorate of Fisheries, Bergen, Norway. 54 p. + appendices.

LARGE, P. A., C. HAMMER, O. A. BERGSTAD, J. D. M. GORDON, and P. LORANCE. 2002. Deep-water fisheries of the Northeast Atlantic: II Assessment and management approaches. J. Northw. Atl. Fish. Sci., 31: $151-163$ (this volume).

MAGNÚSSON, J. MS 1998. Deep water fisheries at Iceland. ICES C.M. Doc., O:66, 16 p.

MAGNÚSSON, J.V., O. A. BERGSTAD, N.-R. HAREIDE, J. MAGNÚSSON, and J. REINERT. 1997. Ling, blue ling and tusk of the northeast Atlantic. TemaNord, 535: $58 \mathrm{p}$.

MAGNÚSSON, J., J. V. MAGNÚSSON, and K. B. JAKOBSDÓTTIR. 2000. Deep-sea fishes. Icelandic contributions to the deep-water research project, EC FAIR Project CT 95-0655, 1996-1999. Hafrannsoknastofnun Fjolrit, No. 76: 164 p.

MERRETT, N. R., and R. L. HAEDRICH. 1997. Deep-sea demersal fish and fisheries. Chapman Hall, London, $282 \mathrm{p}$.

PECHENIK, L. N., and F. M. TROYANOVSKY. 1970. Trawling resources on the North Atlantic continental slope. Israel Program for Scientific Translations, 1971, Cat. No. 5977, 66 p.

PIÑEIRO, C. G., J. M. CASAS, and R. BAÑÓN. 2001. The deep water fisheries exploited by Spanish fleets in the Northeast Atlantic: a review of the current status. Fish. Res., 51: 311-320.

PINHO, M. R., J. M.GONÇALVES, H. R. MARTINS, and G. M. MENEZES. 2001. Some aspects of the biology of the deep-water crab, Chaceon affinis (Milne-Edwards and Bouvier, 1894) off the Azores. Fish. Res., 51: 283295.

RÄTZ, H.-J. 1984. Qualitative und quantiative Untersuchungen der Icthyozönoze in der archibenthiscen Zone des Rockall-Grabens und umliegender Bänke (Westbritische Gewässer). Mitteilungen aus dem Institut für Seefischerei, 34: $152 \mathrm{p}$.

REINERT, J. 1995. Deep-water resources in Faroese waters to the south, southwest and west of the Faroes - a preliminary account. In: Deep-water fisheries of the North Atlantic Oceanic Slope, A. G. Hopper (ed.). Kluwer Academic Publishers, The Netherlands, p. 202-225.

REIS, S., D. SENA-CARVALHO, J. H. DELGADO and M. AFONSO-DIAS. MS 2001. Historical overview of the black scabbardfish (Aphanopus carbo Lowe, 1839) fishery in Madeira Island. NAFO SCR Doc., No. 103, Serial No. N4491, 6 p.

RICO, V., J. I. SANTANA, and J. A. GONZÁLEZ. 1999. Técnicas de pesca artesanal en la isla de Gran Canaria. Monografias del Instituto Canario de Ciencias Marinas, 3: $318 \mathrm{p}$. 
SILVA, H. M. MS 1987. An assessment of the Azorean stock of kitefin shark, Dalatias licha (Bonn., 1788). ICES C.M. Doc., G:66, 10 p.

THOMSEN, B. MS 1998. Faroese quest of orange roughy in the North Atlantic. ICES C.M. Doc., O:31, 8 p.

TROYANOVSKY, F. M., and S. F. LISOVSKY. 1995. Russian (USSR) fisheries research in deep waters (below $500 \mathrm{~m}$ ) in the North Atlantic. In: Deep-water fisheries of the North Atlantic Oceanic Slope, A. G. Hopper (ed.). Kluwer
Academic Publishers, The Netherlands, p. 357-366.

VINNICHENKO, V. I. MS 1998. Alfonsino (Beryx splendens) biology and fishery on the seamounts in the open North Atlantic. ICES C.M. Doc., O:13, 13 p.

VINNICHENKO, V. I., and V. N. KHLIVNOY. MS 2001. Russian deep-sea investigations and fisheries in the northeast Atlantic in 2000. Working Document, ICES Study Group on the Biology and Assessment of DeepSea Fisheries Resources, 19 . 